Post-print version of: Rimmer, M. (2015) ‘Harmony or Discord? Understanding children’s valuations of a Sistema-inspired initiative' in British Journal of Music Education

\title{
Harmony or Discord? Understanding children's valuations of a Sistema-inspired initiative
}

Abstract

This article explores children's reflections on the value of their participation in In Harmony, a social and music education programme whose approach and philosophy derives from the Venezuelan 'El Sistema' ('The System') model. More specifically, through an analysis of participating children's accounts $(n=111)$ and an exploration of the key patterns evident within children's attribution of value to their In Harmony participation, the article highlights a series of ways in which the initiative's approach to music and musical learning threaten to undermine its core aims.

Keywords: In Harmony; Sistema; value;

\section{Introduction}

This article explores children's reflections on their participation in the In Harmony initiative, a social and music education programme whose approach and philosophy derives from the Venezuelan El Sistema ('The System') model. Working with disadvantaged children and young people through an immersive symphony orchestral model, El Sistema has attracted a good deal of interest and support in recent years, with Sistema-inspired projects today established in more than 60 countries (Creech et al., 2013) and reaching an estimated one million children (Sistema Global 2015). In terms of its aims, England's Sistema-inspired initiative follows the El Sistema model closely. It has thus been characterised as 'a national programme that aims to inspire and transform the lives of children in deprived communities, using the power and disciplines of community-based orchestral music-making' 
(ACE 2013: n.p.). Similarly reflective of the El Sistema initiative, In Harmony describes its projects as not just music education initiatives but 'ambitious social action programmes' designed to 'transform the lives of children, young people and their communities' (Sistema England, 2015: n.p.).

In Harmony's development in England can be traced back to 2009, when three projects were established in Norwich, Lambeth and Liverpool, with funding from the Department for Education (DfE) and Arts Council England (ACE). With the publication of the first National Plan for Music Education (DfE 2011), it was announced that the programme would be expanded such that by 2012, four new In Harmony initiatives had been established (in Leeds, Telford, Newcastle and Nottingham). To date, In Harmony claims to have engaged with approximately 3,300 children from more than 80 schools in England (Sistema England, 2015) and the Department for Education and Arts Council England have committed to continue funding the programme until at least 2018.

\section{In Harmony and El Sistema research}

Despite the success of both El Sistema and Sistema-inspired initiatives in attracting support from national governments and private sponsors, as Geoff Baker notes in his in-depth research on the Venezuelan phenomenon, the working model on which El Sistema is based has, for some time, suffered from a 'lack of support from rigorous, objective research' (2014: 5). Indeed, despite offering numerous claims about the value of the many Sistemainspired programmes now operating across the world, a recent review of research and evaluation conducted by Sistema Global conceded that 'there has been little funded 
research...and many studies cited here represent self-funded student dissertations or theses' (Creech et al. 2014: 19).

Nevertheless, England's Sistema-inspired initiative, In Harmony, has been subject to ongoing independent evaluation by the National Foundation for Educational Research (NFER), with several reports issuing as a result (Lord et al, 2013; Lord et al. 2015). The aim of the NFER research has been 'to track and measure the impacts of the current six In Harmony programmes' (Lord et al. 2013: 2), with 'impact' primarily interpreted in terms of 'the social, emotional and educational development of children' (Lord et al. 2013: 2) and assessed through a combination of key stage attainment measures in literacy and numeracy, pupil attendance figures, a pupil questionnaire and case study visits. Illuminating as these reports may be in certain regards however, they ultimately provide very little insight into the ways participating children have responded to the initiative.

Consider the pupil questionnaire employed by NFER. This appears to suffer from a number of weaknesses, especially in relation to its effort to explore children's 'Musical enjoyment and achievement' (Lord et al., 2013: 45). For example, questions about In Harmony participation are framed - far too broadly - in terms of 'music' (such that responses about enjoying, learning or playing music may not necessarily relate to In Harmony activities at all). Secondly, the statements against which participating children are able to register their responses in respect of 'musical enjoyment and achievement' appear to have been framed in an exclusively positive way (e.g., 'I am learning a lot in music', 'I like playing my instrument in class', 'I am able to play more difficult pieces now'), while the response options to such statements - 'Yes a lot', 'Yes a bit', 'No', 'Not sure' and 'No response' - are 
also somewhat skewed towards the elicitation of agreement. The pupil questionnaire thus appears to have provided only minimal scope for children to register their disengagement/dislike and no scope at all for the elaboration of any criticisms.

It is also worth noting that children's own words are conspicuous by their relative absence across the two NFER reports. When verbatim quotations are offered to help illuminate and substantiate key claims, the overwhelming majority issue from school heads and teachers (15 quotes), parents and grandparents (7 quotes) or else In Harmony managers and tutors (5 quotes). Children's reflections, meanwhile, are cited on just two occasions across both reports and in each case they take the form of endorsements (one in relation to music learning, another to a child's membership of a project steering group). Such an underrepresentation of children's reflections is quite surprising given that more interviews were undertaken with them (38 in total) than any other stakeholder group (22 parents, 20 heads/teachers and 12 In Harmony managers/tutors, see Lord et al. 2013: 47). In a marked contrast to this, In Harmony's own promotional and advocacy materials (see, for instance, the Sistema England ${ }^{1}$ website), make quite prominent use of selected statements from participating children².

Yet given In Harmony's espoused intention to 'inspire and transform the lives of children in deprived communities' (ACE 2013: n.p.), the matter of participating children's responses to the initiative would appear quite crucial to its claims for success. In fact, questions about In Harmony's ability to stimulate and retain children's interest ought to be of interest to observers for good reasons. I am referring here to the long-noted difficulties of generating and sustaining children's interest in school music, especially when it centres on the 
established Western classical music canon (Vuillamy 1978; Shepherd and Vulliamy 1994;

Green 2006, 2013). Numerous studies have reported that music in the school curriculum is often described as 'out of touch' or perceived as irrelevant by children (Harland et al. 2000; Green, 2001; Sloboda, 2001; Lamont \& Maton 2008;) and scholars have pointed towards the cultural 'dissonance' between the music of school lessons and that pervading children's lives outside of school as a key means of understanding this (e.g., Mills, 1994; Ross, 1995; Stalhammar, 2000; Boal-Palheiros \& Hargreaves 2001; Saunders 2010).

Responses to this challenge have seen a number of voices within music education philosophy affirm the need to move away from the Western music aesthetic (and its associated ideological premises) and instead towards a vision of music education which stresses music's functions and role as an activity, practice or form of praxis, whose value needs to be understood in relation to music's use and the meanings thereby attributed to it (Alperson, 1991; Elliott 1995; Small 1998; Bowman 2005; Lines 2005; Regelski 2006, 2016). Such thinking appears to have informed a growing recognition, on the part of music educators, of the need to grant pupils greater choice about what music is learnt, to encourage more self-directed work and employ informal music learning practices within formal environments (e.g., Folkestad, 2006; Green, 2008; Snell \& Söderman 2014). While the 'Musical Futures' initiative provides perhaps the best example of this kind of informal learning approach in the UK, since the turn of the millennium a number of other (predominantly state-supported) initiatives have also set considerable store by the greater use of informal music learning approaches within school contexts. Indeed, such initiatives might be seen as part of a wider effort, on the part of schools and music providers, to 
'connect their music provision more meaningfully with young people's own interests, passions and motivations' (Hallam and Creech, 2010:343).

In Harmony's adoption of an orchestral model and a formalized approach to pupils' instrumental learning (Dobson 2016), together with music mostly drawn from the established Western canon therefore appears to go against the grain of recent thinking in music education. Yet not only does the In Harmony initiative appear to set such concerns largely aside, it seeks to produce transformative effects within those same family and community contexts in which the aforementioned 'dissonance' with school music might be seen as primarily rooted. Furthermore, given the enduring socio-economic cleavages in tastes for classical music across British society (Bennett et al. 2009), In Harmony's approach would appear liable to present notable challenges - at the level of children's active engagement - for a programme operating within some of England's most deprived communities.

In light of the aforementioned absence of research into children's responses to In Harmony, combined with the noted challenges of school-based music education initiatives employing classical music forms, this article draws on extensive empirical material to engage directly with children's accounts of their participation, especially in terms of the ways they perceived value in this.

\section{Research Focus and Approach}

The aim of the research project whose findings are detailed below centred on questions about how participating children attributed value to their involvement in In Harmony. In line 
with the broader aims of the Arts and Humanities Research Council's (AHRC) 'Cultural Value Project' of which it formed one part, the study ${ }^{3}$ sought 'to contribute to a better understanding of the value of arts and culture to individuals and society' (Crossick \& Kaszynska, 2014: 123). In this, the research adopted a quite open approach to questions of 'value'. That is, rather than focussing on pre-defined aspects of cultural experience or supposed benefit (or indeed 'impact'), attention centred upon the ways in which children described the satisfactions and pleasures which they derived from musical activities. While In Harmony participation formed the core subject of interest in this regard, the research also sought to understand more about the reasons why certain kinds of musical experience and activity resonated with children. Consequently, an effort was made to explore the bases or foundations upon which children's valuing of music and music-related activities rested. The research thus sought to go beyond questions about which musical texts or activities were of perceived value to children, to also attend to their qualities and attributes, as well as the relations and contexts bound up with them. In this way, the research approach was characterised by a concern with questions of how and why in terms of children's figuring of value in relation to both In Harmony and further musical activities.

In order to access children's accounts, the research project employed semi-structured interviews, undertaken with primary-aged pupils in four schools involved in the In Harmony initiative. In order to reflect variations across the different projects in England, three case studies of In Harmony projects were selected. In terms of their functioning, In Harmony projects are delivered through partnership operating models whose lead partners are either National Portfolio Organisations ${ }^{4}$ or else a local music services. Two of the case studies selected for inclusion in this study reflected this variation (the Newcastle and Telford case 
studies respectively), with the sample also including one project delivered by a community arts organisation (in Norwich). Key information relevant to the chosen case studies is presented in Table 1.

\section{Table 1: In Harmony case studies}

Although there existed noteworthy differences between the chosen case study projects - in terms of their facilitation of In Harmony activities - for reasons to be made apparent below, these will not be elaborated here. A number of important commonalities can be noted however. Each of the schools involved were located in areas of noted deprivation ${ }^{5}$ and numerous core features of the El Sistema approach, as incorporated into the In Harmony programme, were also evident: each child learned to play a symphony orchestra instrument; learning activities centred on group instrumental and general musicianship sessions; repertoire was predominantly drawn from the classical Western canon; learning activities were led by tutors with formal music learning backgrounds and a 'whole school' (i.e., mandated) approach to child participation was adopted in all but one of the schools involved (Catton Grove, Norwich). In addition, regular public performance opportunities were built into projects, as were visits to other cultural events and institutions, where funding permitted. Given the reduced funding available to the Norwich-based project after $2012^{6}$, this implied less contact time between music tutors and pupils, less teacher involvement, fewer supplemental activities (e.g., events, visits, etc.), and none of the selective 'advanced' pathways offered to children in Newcastle and Telford'. 
A total of 111 interviews were undertaken, with the sample weighted more towards participants of the fully-funded projects in Telford $(n=42)$ and Newcastle $(n=43)$ than Norwich $(n=26)$. The sample was stratified within schools to accommodate, in approximately equal proportions, the participating boys and girls from across year groups two to six (aged from six to eleven). Participating children were selected randomly, either by research team members or teachers, with interviews taking place on school premises, mostly during the school day and typically lasting between 25 and 45 minutes.

As is suggested above, the interviews set out to cover not only children's responses to In Harmony but also gather information about other musical and music-related activities in which children perceived value. In order to encourage the flow of discussion, within interviews children were presented, in turn, with photo cards depicting an array of images corresponding to aspects of both In Harmony participation as well as further musical activities, genres and modes of listening. From these, children were asked to select a few favourites before ranking these in order of preference. Children were also invited to suggest any other activities not depicted on the cards. The aim of this 'ranking game' was to serve as the basis for discussion, as children were asked to elaborate upon their choices and offer reasons for them. Since many children encountered difficulties in giving expression to explicit notions of value within interviews, various attempts to help them frame and figure 'value' or 'the valuable' (by using proxy terms and offering examples) were made ${ }^{8}$. Interviews were subsequently analysed with particular regard for consistencies, patterns or other regularities in terms of how children saw value in musical activities and the way(s) in which this was framed by them. 


\section{Research Findings}

Before moving on to consider children's responses to In Harmony participation, a few words are warranted to describe the ways children detailed the ways they employed and valued music and related activities within their everyday lives. One finding to emerge quite prominently across the whole sample was the notable level of expressed interest in popular music. This was perhaps most pronounced amongst younger female respondents, very many of whom expressed variously passionate degrees of interest in the music of pop groups (e.g., One Direction, JLS), or else solo pop artists (such as Katy Perry, Jessie J, Justin Bieber), although by age 10 numerous boys were beginning to express comparable degrees of interest (largely in beat-driven musical forms such as Rap, Hip-Hop and dance).

Activities involving significant others (especially family members) and taking place within domestic contexts also emerged prominently within many children's accounts of what they valued in relation to musical activity. Undoubtedly significant in this was the fact that, when activated within living rooms, bedrooms and kitchens, music very often brought with it a compelling visual dimension. In fact, watching popular music videos via YouTube, in domestic settings (typically either on 'my laptop', 'Mum's tablet' or similar), emerged as the most common means of accessing musical texts. Unsurprising then, was the prominence accorded to matters of image, 'look', style or appearance within many children's attempts to tell us what they saw as valuable in relation to popular music.

Dancing and singing along to pop songs were also commonly reported as valued activities (although more by girls than boys as a general rule). While dancing often appeared to be valued for its physical and kinetic properties, it also offered scope for creative expression as 
much as emulation, for accessing feelings of freedom ('just going a bit crazy'), as well as implicitly holding out the possibility of such pleasures being amplified by the coparticipation of others. In a similar vein, singing along to pop songs emerged as a commonly enjoyed activity for many. Whilst some told us that they were 'good at singing', for many others, questions about vocal quality appeared largely beside the point. Rather, singing along appeared to primarily function as another way - like dancing - of getting closer to 'the music' or, perhaps more pertinently in such cases, 'the song' (in terms of the representational or symbolic meanings on offer). Indeed, popular music's lyrics clearly offered another source of value for many interviewees and in quite a number of cases such as when children stated how One Direction songs were valuable due to being 'about something real' - the perceived importance of lyrical meanings could not be doubted.

In numerous ways then, respondents incorporated popular music into their lives in ways which spoke of a host of valued experiences and suggested that there appeared to be a great deal going on beneath the commonly stated 'fun' on offer. While not all participants engaged with popular music forms in the same ways or to the same degree, it was clear that many saw it as rich with pleasures and potential.

\section{In Harmony participation}

A first issue to note here concerns the lack of any substantial differences in children's overall responses to In Harmony across the three case studies. Although some children certainly appeared to derive satisfaction from the distinctive experiences afforded by individual projects (e.g., Telford participants' visit to the Royal Albert Hall), looking across the accounts as whole, factors related to children's individual circumstances and the nature of their 
broader engagements with music appeared more important - in terms of informing their evaluation of In Harmony participation - than project-specific variations.

Overall, within each of the case studies, children expressed quite divergent responses to In Harmony; ranging from expressions of notable satisfaction and pleasure through to ambivalence, lack of interest and positive dislike. Rather than attempt to account for the idiosyncrasies of individual accounts, what follows seeks to broadly map this terrain, thereby seeking - as a means of unpicking the foundations or bases of value drawn upon within children's accounts - to understand the correlations and common themes emerging out of the accounts offered.

To begin with factors corresponding to positive evaluations of In Harmony participation, a first factor to note concerns the important role of parental validation. Indeed, parental interest in and support for children's musical instrument learning seemed to function like something of a necessary (although not sufficient) condition for children's expressed valuing of In Harmony participation:

Why do you enjoy playing [music] $?^{9}$ Because I get to take my cello home...I like when I can take it home...I just want my Mum and Dad and sister to see (Boy, Year 2)

They [parents] find it quite fascinating...they want me to be in an orchestra in front of loads of people (Boy, Year 3) 
Parental validation could take a number of forms, but most usually included the provision of practice and performance opportunities at home, the encouragement to practice and most pronounced - parents' attendance at public performances. Such validation was not exclusively restricted to parents either; older siblings and other family members might also perform similar roles. Receiving praise and acknowledgement for their efforts from significant others thus seemed to function, for many children, as an important way of establishing the sense in which In Harmony music learning was, indeed, to be valued. ${ }^{10}$

Other influences originating at home could produce comparable effects. Where, for instance, siblings were also engaged in and enjoying In Harmony participation, this also seemed to bolster respondents' sense of its value. In a similar way, the pre-existing and ongoing musicality of older siblings or family members - where the latter had approached music learning via 'formal' routes or played orchestral instruments - also appeared to encourage children's positive evaluation of In Harmony participation:

My brother plays the violin too and he sometimes teaches me...he's been playing since he was 11, now he's 22. He teached me 'Twinkle Twinkle Little Star' (Girl, Year 4)

A further factor to correlate quite strongly with positive responses to In Harmony was the sense, expressed by some children, that they were making good progress in their instrument learning. This was most pronounced amongst the (admittedly few) children who described finding instrument learning 'easy'. 
The music I prefer is things we learn at school. They tell you what to do and give clear instructions. You can just do it like that [clicks fingers] (Girl, Year 6)

While this attitude was most prevalent amongst those children who both detailed positive experiences of broader school life and received parental support in their In Harmony participation, it also held true for a number of children for whom these conditions did not pertain. In such cases, it appeared that children had simply uncovered a previously undiscovered aptitude for instrument playing. In these cases, children's positive responses to In Harmony appeared to stem from a combination of encouragement from music tutors and the fact they had been 'progressed' within their project's learning structures, such that they could access the additional opportunities offered to those progressing best. A further interesting finding concerned the several notable cases of highly committed In Harmony participants who stated a preference for playing their instruments alone (compared to small-group sessions or full orchestra practice).

I only like doing it on my own, but I don't like it, doing it with other people cos they might...do the wrong note...then it won't sound right (Girl, Year 3)

This correlation pertained strongest for pupils expressing notable levels of schoolcommitment and who appeared to derive satisfaction from being perceived, by teachers or In Harmony musicians, to be making especially good progress on their instruments. Indeed, for many of those expressing notably positive attitudes towards In Harmony, something of an adult-oriented (i.e., seeing value primarily in those musical activities validated by adults) and school-committed attitude could be discerned. Given how, in many cases, children 
likened In Harmony sessions to other school lessons, it should perhaps be unsurprising that those viewing scholastic endeavour as rewarding should transfer this attitude onto their In Harmony 'classes'.

While this virtuous cycle and the different elements which fed into it (home/parental validation, school-commitment, aspirational outlook), appeared to fuel positive responses to In Harmony for some children, for others it could mean that In Harmony participation was not seen as either intrinsically motivating or rewarding.

I just find it's kind of boring, cos you're just blowing on it and it's a piece of brass and I just, I just think it's boring...Is it hard? Sort of, it is yeah, it's a bit hard... What about your friends, don't they like it? No. (Boy, Year 6)

So why is it that you don't like practicing at home? I've got better things to do...if I learn it at school I don't know why l'd want to learn it at home (Boy, Year 6)

Although such a lack of interest and enjoyment was sometimes difficult to pin down, it was evident that broader contextual factors - such as when children encountered what they described as too great a degree of challenge in their learning activity - could limit their overall engagement. Below was a typical example:

How are you finding it, learning and playing your instrument? I don't like it...because I keep getting it wrong (Girl, Year 2) 
While such a sense of inadequacy or insufficiency was highlighted by some, more children responded negatively to the physical challenges with which In Harmony-style instrument learning presented them:

It's a little bit hard when you play violin cos it hurts your neck...you have to hold the violin and it really hurts (Girl, Year 4)

How does it feel when you are playing your instrument, do you get a good feeling from it? No, cos your lips sting (Boy, Year 5).

For others, these sorts of physical challenges primarily related to the duration of the music learning activities, where holding instruments for what were seen as excessive periods led children to express opinions such as the following:

It [instrument] gets really heavy if you have to hold it for ages (Boy, Year 6) So which do you prefer, singing or violin? Singing, because you don't have to do it for a long time. If you have to do violin for a long time it starts to hurt your arm (Girl, Year 3)

Indeed, the broader sense of obligation which pervaded many children's accounts of In Harmony participation also seemed to set limits on their perception of it as valuable: 
Could you describe your music sessions? They come in and get violins out and...when *In Harmony Tutor* asks us to play we do, when he tells us to stand up we do and when he asks us to sing we do. And do you like those sessions? Ish [sort of]. (Girl, Year 3)

Miss says practice makes perfect and violin is different to music because you have to do it, you have to do it...[pause]...because you have to do it (Girl, Year 3)

In pointing towards what they saw as a limited range of choices and freedoms inherent to their In Harmony participation (over repertoire, instrument choice, duration of learning sessions), many (and especially older children) set it in some contrast to the ways they approached popular music-related activities. Correspondingly, when children expressed notably avid engagements with popular music and its associated activities, this tended to be accompanied by generally less positive attitudes towards In Harmony:

I [would] like [to play] pop and rock when I get better, because it's got singing to it and everything, and the other one [classical music] is just like music with instruments (Girl, Year 5)

When children were asked to say more about the their experience of In Harmony participation at the level of aesthetic experience (in terms of the sounds, feelings and musical materials involved), a further consistently expressed perception was that the kind of music involved could be best described by terms such as 'calm' or 'smooth'. 
How would you describe the kind of music you do in your music sessions? [long pause] Calm (Girl, Year 3)

For many children, and especially those who had expressed an interest in popular music forms, the calm/smooth nature of In Harmony's aesthetic materials meant that, for various reasons, it failed to hold their interest:

It's like calm and smooth, but the music I listen to is loud (Girl, Year 5)

I thought they [In Harmony initiative] would use not soothing instruments but stuff like piano, drums, the ones that can actually get beat in them (Boy, Year 4)

Many children thus framed the music employed within In Harmony in terms of an absence or lack (e.g., 'just instrumental', 'just music', 'just like music with instruments'), especially when they had previously revealed avid engagements with popular music. Yet that group of children who expressed perhaps the lowest levels of interest in In Harmony, were those who detailed quite active out-of-school musical lives which centred on popular music genres. The influence of both siblings and parents was again significant in this, but this time operating to diminish rather than enhance children's perceptions of In Harmony's value:

So do you think you'll carry on with the violin? When I get older I'm not gonna play it. No? Why? It gets your arms tired. I would rather play the guitar...my Dad plays a guitar. He taught me how to play guitar (Girl, Year 3) 
My [older] sister plays drums...I'd rather play drums...I've been playing violin since half way through year three...its hard and boring, I don't really like it (Boy, Year 4)

\section{Summary}

A number of key themes emerge from the foregoing discussion. In many ways the nature of these highlight the need for recognition of how factors both imminent to and lying beyond children's participation in In Harmony could pre-dispose them towards the adoption of particular kinds of stances towards it. Thus the role of parents and siblings in validating (or not) In Harmony participation emerged quite prominently. So, it seemed, did children's broader attitudes towards schooling and the school environment (as a source of validation in its own right). Similarly, the ways of engaging with and uncovering value in musical activities within family and domestic contexts appeared to incline children towards valuing In Harmony participation to greater or (for the most part) lesser degrees.

In other respects, the more immediate and embodied dimensions of children's encounters with In Harmony came to the fore. Challenges in handing or holding instruments, or else perceptions of the sounds created as somehow lacking in desirable qualities were notable here. Indeed, the absence, within the In Harmony initiative, of some of the valued visual, representational and kinetic aspects of popular music forms emerged quite prominently within many accounts. At other times, the obligatory nature of In Harmony participation set it in contrast to some of the valued dimensions of popular music-related activities (where there lay associations with freedom, choice, self-directedness and play). 
These matters might alert us to fact that children's responses to In Harmony cannot be meaningfully understood or articulated without reference to the values which permeated children's wider musical and indeed cultural lives. When such values are taken into account, the picture of In Harmony which emerges is one of an initiative which, despite its appeal to some children, generally fails to connect meaningfully with many children's own musical interests, passions or motivations and, furthermore, appears to set itself against those modes of musical valuing commonly embedded within the deprived family and community contexts which it seeks to transform.

Wordcount: 6114 


\footnotetext{
${ }^{1}$ Sistema England is the name of the charity set up by Julian Lloyd Webber in 2010 (initially called In Harmony Sistema England), to help raise funds for the three In Harmony pilot programmes. In 2013 it changed its name to Sistema England and assumed the wider mandate of supporting all Sistema-inspired programmes in England. Its website can be found at: http://www.sistemaengland.org.uk/

${ }^{2}$ At the time of writing, the Sistema England website's main banner displays images and quotations from children participating in In Harmony. These quotations include: 'You feel special because you're part of something great - it's a really nice feeling' (Adiya, Sistema England Young Leader) and 'I want to create an orchestra that is full of young like-minded people who are passionate about music and enjoy creating it together as one big family' (Victoria, Sistema England Young Leader).

${ }^{3}$ This project was entitled 'Understanding the cultural value of In Harmony-Sistema England'.

${ }^{4}$ These organisations are regularly funded by ACE, typically in the form of rolling 3-year funding agreements.

${ }^{5}$ Ranging from $35.8 \%$ (Old Park Primary) to $61.3 \%$ (Hawthorn School), the percentage of children eligible for free school meals was above the national average at all of the participating schools.

${ }^{6}$ The In Harmony project in Norwich lost its funding in 2012. Since this time it has sustained a reduced range of activities, under the rubric 'Sistema in Norwich', through donations, grant bidding and corporate sponsorship (see: http://www.sistemanorwich.org.uk/our-supporters).

${ }^{7}$ A weekend school was available to the best young players in Newcastle as was membership of a 'Creative Ensemble' in Telford.

${ }^{8}$ Despite these efforts, it was very often the case that what children deemed to be of value was also what they found pleasurable or enjoyable. Interviews therefore adopted an exploratory mode, aiming to draw out some of the implicit meanings, associations and connections between things broadly deemed as 'good' and the ideas lying behind such assessments.

${ }^{9}$ Both here and in what follows, questions asked by members of the research team are presented in italics.

${ }^{10}$ By way of counterexample, in many of the cases where children demonstrated a relative lack of interest in their instrument learning, when asked to describe how parents felt about their music learning they either had little to relate or else told us how their parents had, for example, said 'Nothing' (Boy, Year 5).
} 


\section{References}

ALPERSON, P. (1991) What should one expect from a philosophy of music education? Journal of Aesthetic Education, 25(3), 215-29.

ARTS COUNCIL ENGLAND (ACE) (2013) In Harmony. Accessed 12 May 2014

http://www.artscouncil.org.uk/funding/apply-funding/funding-

programmes/harmony/

BAKER, G. (2013) ‘Researching El Sistema (2)’ Accessed 12 May 2014

https://geoffbakermusic.wordpress.com/el-sistema-older-posts/researching-elsistema-2/

BAKER, G. (2014) El Sistema: Orchestrating Venezuela's Youth. Oxford: OUP.

BAKER, G. (2016) 'Editorial Introduction: El Sistema in critical perspective'. Action, Criticism, and Theory for Music Education, 15(1), 10-32.

BOWMAN, W. (2005) 'Music education in nihilistic times'. Educational Philosophy and Theory, 37(1), 29-46

CREECH, A., GONZALEZ-MORENO, P., LORENZINO, L. \& WAITMAN, G. (2013) El Sistema and Sistema-Inspired Programmes: A Literature Review of research, evaluation, and critical debates. Sistema Global: San Diego, California.

CROSSICK, G. \& KASZYNSKA, P. (2014) Under construction: Towards a framework for cultural value. Cultural Trends 23(2), 120-131.

DEPARTMENT FOR CHILDREN, SCHOOLS AND FAMILIES (DCSF) (2008) Unprecedented investment in music education has the power to change children's lives. News Release 0121 issued by The Government News Network on 20 June.

DEPARTMENT FOR EDUCATION (DfE) (2011). Music Education in England - A Review by Darren Henley. London: DfE \& DCMS. 
DOBSON, N. (2016) Hatching plans: Pedagogy and discourse within an El Sistema-inspired program. Action, Criticism, and Theory for Music Education, 15(1), 89-119.

ELLIOTT, D. (1995) Music matters: A new philosophy of music education. New York: Oxford University Press.

FOLKESTAD, G (2006) Formal and informal learning situations or practices vs formal and informal ways of learning, British Journal of Music Education, 23(2), 135 - 145.

GREEN, L. (2006) Popular music education in and for itself, and for 'other' music: current research in the classroom. International Journal of Music Education, 24(2), 101-118.

GREEN, L. (2008) Music, Informal Learning and the School: a New Classroom Pedagogy. London: Ashgate.

HALLAM, S. \& CREECH, A (2010) Where Now? In S. Hallam \& A. Creech (Eds.) Music Education in the $21^{\text {st }}$ Century in the United Kingdom: Achievements, analysis and aspirations. London: Institute of Education.

HARLAND, J., KINDER, K., LORD, P., STOTT, A., SCHAGEN, I., HAYNES, J., et al. (2000). Arts Education in Secondary Schools: Effects and Effectiveness. Slough: NFER.

LAMONT, A., HARGREAVES, D.J., MARSHALL, N.A. AND TARRANT, M. (2003) Young people's music in and out of school. British Journal of Music Education, 20(3), 229-41.

LAMONT, A., \& MATON, K. (2008). Choosing music: Exploratory studies into the low uptake of music GCSE. British Journal of Music Education, 25(3), 267-282.

LINES, D. K. (2005) (ed.) Music education for the new millennium: theory and practice futures for music teaching and learning. Oxford: Blackwell.

LORD, P., SHARP, C., DAWSON, A., MEHTA, P., WHITE, R. AND JEFFES, J. (2013) Evaluation of In Harmony: Year 1 Interim Report. Slough: NFER. 
LORD, P., SHARP, C., MEHTA, P., AND FEATHERSTONE, G. (2015). Evaluation of In Harmony, Year 2. Slough: NFER.

MUSICAL FUTURES (2015) Music matters to our kids and is good for society [Accessed July 152016 at https://www.musicalfutures.org/]

REGELSKI, T. (2006) Reconnecting music education with society. Action, Criticism, and Theory for Music Education, 5/2: http://act.maydaygroup.org/articles/Regelski5 2.pdf REGELSKI, T. (2016) A Brief Introduction to a Philosophy of Music and Music Education as Social Praxis. Abingdon: Routledge.

SISTEMA ENGLAND. 2015. About. Accessed May 122015.

http://www.sistemaengland.org.uk/about/

SHEPHERD, J., AND VULLIAMY, G. (1994) The struggle for culture: A sociological case study of the development of a national music curriculum. British Journal of Sociology of Education, 15(1), 27-40.

SÖDERMAN, J. \& FOLKESTAD, G. (2004) How hip-hop musicians learn: strategies in informal creative music making. Music Education Research, 6(3), 313-326.

SMALL, C. (1998) Musicking: The meanings of performing and listening. Middletown, Connecticut: Wesleyan University Press.

SNELL, K, \& SÖDERMAN, J. (2014) Hip-hop within and without the academy. London: Lexington Books.

STALHAMMAR, B. (2000) The spaces of music and its foundation of values: Music teaching and young people's own music experience. International Journal of Music Education, 36(1), 35-45. 
Table 1

\begin{tabular}{|c|c|c|c|c|}
\hline Project name & $\begin{array}{c}\text { Year } \\
\text { Initiated }\end{array}$ & $\begin{array}{c}\text { Schools } \\
\text { involved in } \\
\text { study }\end{array}$ & $\begin{array}{c}\text { Delivery } \\
\text { organisations and } \\
\text { further partners }\end{array}$ & $\begin{array}{c}\text { Weekly music } \\
\text { learning } \\
\text { activities }\end{array}$ \\
\hline $\begin{array}{c}\text { In Harmony } \\
\text { Telford and }\end{array}$ & 2012 & $\begin{array}{c}\text { Old Park } \\
\text { Primary } \\
\text { Stoke-on-Trent }\end{array}$ & $\begin{array}{c}\text { Music; Birmingham } \\
\text { Symphony } \\
\text { Orchestra; } \\
\text { Manchester } \\
\text { Camerata }\end{array}$ & $\begin{array}{c}\text { 3hrs compulsory } \\
\text { (plus after-school } \\
\text { offer) }\end{array}$ \\
$\begin{array}{c}\text { In Harmony } \\
\text { Newcastle- } \\
\text { Gateshead }\end{array}$ & 2012 & $\begin{array}{c}\text { Hawthorn } \\
\text { School }\end{array}$ & $\begin{array}{c}\text { The Sage } \\
\text { Gateshead }\end{array}$ & $\begin{array}{c}\text { 3hrs compulsory } \\
\text { (plus weekend } \\
\text { offer) }\end{array}$ \\
\hline $\begin{array}{c}\text { Sistema in } \\
\text { Norwich }\end{array}$ & 2009 & $\begin{array}{c}\text { Catton Grove } \\
\text { Primary; } \\
\text { Norwich } \\
\text { Primary }\end{array}$ & $\begin{array}{c}\text { Norfolk \& Norwich } \\
\text { Community Arts } \\
\text { (NORCA) }\end{array}$ & $\begin{array}{c}\text { Catton: } 3 \mathrm{hrs} \\
\text { optional; } \\
\text { NPA: } 1 \mathrm{hr} \text { (whole } \\
\text { class) plus } 2 \mathrm{hrs} \\
\text { optional }\end{array}$ \\
\hline
\end{tabular}

